\title{
Renovation of depressed areas using methods of transpersonal socionics
}

\author{
Antonina Suzdaleva ${ }^{1,2, *}$, Valentina Kurochkina ${ }^{1}$, Maria Kuchkina $^{2}$, Bolortuya Jargalsaihan ${ }^{1}$ \\ ${ }^{1}$ Moscow State University of Civil Engineering, 26, Yaroslavskoye Shosse, 129337, Moscow, Russia \\ ${ }^{2}$ Moscow National Research University "Moscow Power Engineering Institute", 14, \\ Krasnokazarmennaya Street, 111250, Moscow, Russia
}

\begin{abstract}
Depressed areas are naturally degraded sections of urbanized territories. Their existence is always a cause of deterioration in social, economic and environmental conditions. Renovation of depressed areas is an activity that ensures the restoration of favorable conditions in the areas they occupy. Renovation is necessary to ensure the safety of the population and normal living conditions. There are several types of depressed areas that differ in their scale. Depressed objects are individual abandoned buildings and territories around them. Depressed urban districts include parts of the territory of cities with low or naturally declining quality of life, which is characterized by destroying buildings and structures, as well as undeveloped and unsettled sections. Depressed industrial zones are vast territories surrounding complexes of abandoned industrial enterprises. A separate type of depressed areas are ghost towns. They are considered urban-type localities with collapsing buildings and degraded infrastructure, abandoned by residents or a significant part of them. A characteristic feature of all types of depressed areas is their uncontrolled colonization by various organisms. For this reason, depressed areas can be considered as unmanageable natural and technical systems. Transpersonal socionics is an interdisciplinary science, the subject of which is the study of the interaction of various organizational structures and social groups consisting of individuals united by common interests. Such aggregate elements of society can be divided into several categories that differ in the nature of their involvement in the renovation process. They are designated as economic, territorial, technological, administrative, political, and social stakeholders. For each of the categories, the nature of risks caused by the existence of depressed areas is described. Special attention is paid to the problems of environmental risks of various categories of stakeholders. Based on the use of the principles of transpersonal socionics, a method is proposed that allows providing a systematic unified approach to the development of programs for the renovation of depressed areas on the basis of the consideration of all parties involved in this problem (stakeholders).
\end{abstract}

\footnotetext{
* Corresponding author: suzdalevaal@yandex.ru
} 


\section{Introduction}

Depressed areas are sections of urbanized territories that are subject to sustained degradation. The characteristic features of this process are abandoned buildings, destruction of infrastructure, deterioration of social, economic and environmental conditions. Depressed areas can have a negative impact on the living conditions of people living in the territories bordering them. This can manifest itself, for example, in the form of the spread of pollutants in the environment when the tightness of storage tanks for various substances in abandoned industrial facilities is violated. In addition, in most cases, depressed areas become an environment suitable for the life of some undesirable plant and animal species. As a result, unmanaged natural-technical systems (NTS) arise [1]. Some organisms (rats, flies, blood-sucking mosquitoes, etc.) that multiply in large numbers in NTS are carriers of infectious diseases. Other animals that live in them, such as packs of feral dogs, can pose a threat to human life. Among other things, abandoned buildings and structures often become a source of criminal danger to the surrounding population [2]. The result is the loss by the urban districts surrounding the depressed areas, a positive image. The most prosperous part of the population and offices of prestigious organizations are moving to other parts of the city. Maintenance of abandoned buildings becomes unprofitable, and they gradually degrade. Thus, a many depressed areas tend to expand spontaneously.

The scale of depressed areas can vary significantly. According to this feature and other features, they can be divided into several types:

- depressed objects - individual abandoned buildings and territories around them;

- depressed urban districts - parts of the territory of cities with low or naturally decreasing quality of life, which is characterized by destroying buildings and structures, as well as undeveloped and unsettled sections - wasteland [3];

- depressed industrial zones - vast territories surrounding complexes of abandoned industrial enterprises [4];

- ghost towns - settlements abandoned by the population or a significant part of it, with collapsing buildings and degraded infrastructure $[5,6]$.

Regardless of the size and other features, the occurrence of any depressed areas causes a complex of risks for the population, which increase as they degrade. For this reason, ignoring the existence of depressed areas and trying to isolate them, as a rule, only lead to aggravation of problems. This determines the relevance of renovation, which in this case means active actions to eliminate depressed areas and create conditions that ensure the normal life of the population in the areas occupied by them [7, 8]. To denote this activity, the similar terms revitalization [9] and redevelopment [10] are also used.

The effectiveness of renovation of depressed areas can significantly increase with a systematic approach to solving the problem, based on the generalization of experience gained when working on various objects. This will allow predicting in advance the occurrence of various problems caused by the renovation process and promptly eliminating contradictions between its participants.

The purpose of the work was to create a unified renovation methodology that allows identifying the full range of risks associated with the existence and elimination of depressed areas of various types, as well as to provide a systematic approach to the implementation of the actions taken. The main actual material was the results conducted by the authors in 2016-2020. The objects of research were sections of unfinished abandoned buildings and structures in Moscow and the Moscow region, as well as the study of the industrial zone of the Nalaikh district (Mongolia). 


\section{Methods of transpersonal socionics in the field of renovation}

Renovation of depressed areas requires significant financial resources. The justification for the need to invest in this activity in most cases is:

- the need to reduce risks for the population in order to improve the social and political situation;

- obtaining economic benefits from the subsequent use of land plots that have undergone renovation.

These factors can be combined in various ways. So, after the demolition of abandoned and non-recoverable structures that worsen the state of the urban environment, objects are built on the vacant areas that pay for investment in renovation activities.

At the same time, renovation often meets with resistance, both from the broad masses of the population, and some organizations, as well as owners of degraded objects and the land on which they are located. For example, people who live in dilapidated buildings in the central part of cities often do not want to move to other areas during the renovation process. Changing their place of residence can cause them to develop a complex of psychological frustrations and deprivations [11]. Therefore, when developing renovation programs, it is important to identify the full range of stakeholders whose interests may be affected by them, and create a basis for consensus. In current practice, these tasks are performed in the form of a set of preliminary agreements. Their range in each particular case is determined by the renovation organizers based on their accumulated experience. The interests of some parties often fall out of sight and can cause conflicts in the future. The use of methods of transpersonal socionics can eliminate the occurrence of such contradictions. It provides a systematic approach to the timely development of a consensus of interests of all categories of stakeholders and creates the basis for a unified renovation methodology applicable to all objects, regardless of their nature and scale.

Transpersonal socionics is an interdisciplinary science, the subject of which is the study of the interaction of aggregate elements of society in order to develop mechanisms for productive and conflict - free development of society, accompanied by an increase in the well-being of the population while maintaining favorable conditions for its existence [12]. Aggregate elements mean combined (aggregated), on one or another basis, a set of individuals. By their nature, they are very diverse. Any organization or spontaneous association of people can be considered as an aggregate element based on the similarity of their requirements. But in any case, such structures have emergence, that is, they are able to perform tasks of a different, higher order than the individuals who form them individually. In addition, the aggregate elements of society always form a group consciousness, which can acquire a dominant role in motivating human actions. The individual consciousness of incoming individuals who form the aggregate elements of society is influenced by general thinking patterns. In the process of such consolidation, the individual often imperceptibly abandons his previously inherent views. Determining the features of group consciousness in transpersonal socionics performs a task similar to the identification of psychotypes of individuals in classical socionics. Typing group consciousness allows predicting the reaction of aggregate elements to various events, their activity in relation to them, and the form of participation. This fully applies also to the renovation process.

To determine the composition of aggregate elements of society whose interests are affected by the renovation of depressed areas, we can use the method of identification of various categories of stakeholders developed for environmental image-making [13]. Any aggregate element of society that can either influence or be affected by the risks associated with the planned renovation activity is considered as a stakeholder.

The characteristics of different categories of stakeholders are presented in table 1. They are represented by a variety of aggregate elements of society. Their involvement in the 
renovation process is also fundamentally different. The formation of a negative attitude to this activity in society occurs not only as a result of ignoring the interests of certain categories of stakeholders, but also due to the lack of active image-making actions - aimed at purposefully forming a positive image of renovation in their group consciousness. However, image-making gives a tangible result only if it is not limited to formal PR companies, but focuses the attention of stakeholders on reducing the risks of significant threats to them. This allows presenting the renovation of depressed area not only as an activity to improve conditions, but also to justify its necessity as a measure to prevent the inevitable deterioration of the situation that will occur if it is not implemented.

Table 1. Categories of stakeholders, their involvement in depressed areas and the risks associated with them.

\begin{tabular}{|c|c|c|c|}
\hline $\begin{array}{l}\text { Categories of } \\
\text { stakeholders }\end{array}$ & Representatives & Involvement & $\begin{array}{c}\text { The nature of the } \\
\text { risks }\end{array}$ \\
\hline Territorial stakeholders & $\begin{array}{l}\text { Organizations in this } \\
\text { district }\end{array}$ & $\begin{array}{l}\text { Existence in a } \\
\text { depressed area }\end{array}$ & Decline in image \\
\hline \multirow[t]{2}{*}{ Social stakeholders } & \multirow{2}{*}{ Population } & $\begin{array}{l}\text { Deterioration of the } \\
\text { environmental and } \\
\text { criminal situation }\end{array}$ & \multirow{2}{*}{$\begin{array}{l}\text { Threat to health and } \\
\text { life }\end{array}$} \\
\hline & & $\begin{array}{lcc}\text { Illegal use of } \\
\text { depressed areas }\end{array}$ & \\
\hline \multirow[t]{2}{*}{ Economic stakeholders } & $\begin{array}{l}\text { The owners of the } \\
\text { properties and lands } \\
\text { of depressed areas }\end{array}$ & $\begin{array}{l}\text { Getting profit or loss } \\
\text { from the objects they } \\
\text { own }\end{array}$ & $\begin{array}{l}\text { The decrease in } \\
\text { revenues and cost of } \\
\text { ownership, loss of } \\
\text { ownership rights }\end{array}$ \\
\hline & Renovation investors & Gain profit & Material losses \\
\hline $\begin{array}{l}\text { Technology } \\
\text { stakeholders }\end{array}$ & Community services & \multirow{2}{*}{$\begin{array}{l}\text { Ensuring the proper } \\
\text { state of the territory } \\
\text { and monitoring it }\end{array}$} & \multirow{2}{*}{$\begin{array}{l}\text { Deterioration of } \\
\text { social, sanitary and } \\
\text { environmental } \\
\text { conditions }\end{array}$} \\
\hline $\begin{array}{l}\text { Administrative } \\
\text { stakeholders }\end{array}$ & $\begin{array}{l}\text { Government and local } \\
\text { self-government } \\
\text { bodies }\end{array}$ & & \\
\hline Political stakeholders & $\begin{array}{l}\text { Political parties and } \\
\text { movements }\end{array}$ & $\begin{array}{l}\text { Using the issue to } \\
\text { expand the electorate }\end{array}$ & $\begin{array}{llr}\text { Decline } & \text { in } \\
\text { popularity in } & \text { its } \\
\text { disregard } & & \end{array}$ \\
\hline
\end{tabular}

An example of underestimating the risks of social stakeholders is the renovation in Moscow. Despite promises by the authorities to improve living conditions, a significant part of the urban population has a negative attitude to this activity. Many residents are convinced that the renovation is carried out only in the interests of oligarchic circles seeking to develop the central districts. The population is seen as a kind of hindrance, which can be eliminated by moving people to the urban outskirts. On this basis, public protest movements are formed, which are used by some political figures. Perhaps the nature of the group consciousness of Moscow residents would be different if PR campaigns focused not on the expected results of renovation, but on describing the situation that would arise if it was abandoned.

Thus, the deterioration of urban water and heat supply routes in the old districts of Moscow in many places has already reached the maximum level. Frequent leaks pose a threat of soil decompression and the formation of underground gullies. The only real solution to the problem is a systematic renovation of the urban environment, which requires cleaning the territory of dilapidated buildings. If these measures are not implemented, a number of catastrophic consequences are possible, for example, the collapse of residential buildings, the formation of sinkholes and the fall of vehicles and people in them. The basis of this direction of active image-making of renovation can be the dissemination of information in the media about real events of this kind. Social stakeholders should be aware 
with information in a form that is accessible to them that the development of these processes may at some point reach a critical level that really threatens their lives. And then the change of residence will not be in the nature of a planned relocation, but evacuation to temporary accommodation.

\section{Risk analysis of depressed areas}

The risks of depressed areas are multidimensional and specific for each of the stakeholder groups. For territorial stakeholders, the main threat when turning a district into a depressed area is the loss of image. The success of the company's activities is externally manifested, first of all, in the prestige of the urban section where its main office is located. This fully applies to organizations that provide services to the public. Restaurants, ateliers, and law firms tend to leave the area of the city where signs of degradation are beginning to appear.

The risks of social stakeholders are associated with the deterioration of the environmental, sanitary-epidemiological and criminal situation. At the same time, some groups of the population use abandoned objects as unintended places of mass recreation unorganized resorts $[14,15]$. So, in the flooded underground rooms of an unfinished hospital in the Moscow district of Khovrino, a skating rink was arranged when the water is frozen. Much more dangerous are the militarized and extreme games (paintball, airsoft, stalker) that are periodically organized on a number of abandoned buildings in Moscow, involving dozens of people. Groups of extreme diggers get into underground communications, and roofers - on the roofs of buildings. Individuals are engaged in unauthorized dismantling of building structures, for example, to extract scrap metal from structures. All these activities are associated with threats to the health and life of the people involved in these activities (for example, as a result of collapses, falls from high-rise structures and accidents when entering underground communications).

The risks of economic stakeholders are multidimensional. First, these are the risks of owners of land in depressed areas, as well as industrial and household facilities located on them. The value of this property in depressed areas is usually significantly reduced. But some of these properties continue to generate revenue for their owners. Moreover, the weakening of control over these activities, which is associated with the degradation of the urban environment, often increases its profitability. A characteristic phenomenon of depressed areas is the unauthorized construction of retail outlets and small businesses in the service sector. Registration of such objects and licensing of their activities does not meet the requirements of the legislation. In the process of renovation, the owners of such property lose it. Renovation can also be accompanied by a review of land ownership rights, more precisely, establishing their legal validity. Thus, for some owners, especially small ones, renovation creates a threat of termination of economic activity, as well as full or partial deprivation of property rights. An example is the dismantling of many "container" markets in Moscow. These actions, which undoubtedly contributed to the improvement of the urban environment, were not accompanied by measures sufficient to restore small retail outlets. The result was a sharp reduction in the number of Russians engaged in individual entrepreneurship.

Secondly, these are the risks of renovation investors, whom we also consider as economic stakeholders. This category is involved in solving the problems of only those depressed areas, the renovation of which can bring profit. The threat of financial losses in this area can be quite high. In some cases, the renovation process is stopped for economic or political reasons at a stage far from completion. In this situation, investors lose their invested funds. For this reason, large-scale activities in this area are often carried out with partial government funding. But even in this case, the probability of financial losses cannot be excluded. In recent years, major housing renovation projects have been implemented in 
China. But its result was the emergence of dozens of ghost towns, where people for a number of reasons have been refusing to move for several years $[16,17]$. The payback of funds invested in these projects, despite the efforts of the authorities to resolve this issue, is still questionable.

As the main group of technological stakeholders in urban territories, we consider organizations that ensure the normal functioning of public utilities (water supply, sewerage, etc.), maintain the proper state of the urban environment. The occurrence of depressed areas almost always increases the risk of disruption of their normal operation. First of all, this is due to the fact that the deterioration of utility systems in these sections reaches the maximum level. Shutdowns in their work and accidents, create a threat of disconnection from public utilities and for the surrounding districts. In large-scale depressed areas (abandoned industrial zones, ghost towns), the operation of these systems sometimes stops completely [6].

Threat of occurrence of a depressed area is one of the major risks in the areas of administrative management and political activity. Control by the authorities of such territories is difficult due to the destruction of infrastructure and the lumpenization of the population. For example, in some cities in the United States and Western Europe, there are depressed areas where the situation is practically not controlled by the authorities. The very formation of depressed areas is often seen as a failure of economic and social policy. These phenomena can significantly worsen the image of political figures who are at the head of the ruling parties, and lead to their loss of a part of the electorate. On the contrary, successful renovation of existing depressed areas, or even just the intention to implement it, has the opposite effect. Thus, these phenomena affect the interests of almost all political parties and a significant part of political movements, which together can be considered one of the categories of stakeholders of depressed areas.

\section{Adaptation of the classification of environmental risks to the specifics of depressed areas}

The deterioration of environmental conditions that inevitably accompanies the development of depressed areas has a significant impact on the risks of all categories of stakeholders. Thus, territorial stakeholders lose their positive image if they are located in a depressed district next to illegal landfills of household waste and abandoned sections. Social stakeholders view an unfavorable environmental situation as a risk of health loss. For economic stakeholders, the deterioration of environmental conditions creates a threat to reduce the value of real estate and, consequently, financial losses. In addition, the owners of abandoned objects may be additionally required to pay for their damage to the environment. Environmental problems in depressed areas are often the most significant risk factor for administrative and political stakeholders. These problems are an important criterion for evaluating their performance, both by the public and by senior management.

At the same time, reducing the environmental threats of depressed areas is often a much more difficult task than, for example, resuming the operation of industrial enterprises on their territory or stopping the use of their facilities for illegal residence. The complexity of solving the problem is related to the variety of environmental threats. To identify them, as a rule, it is necessary to conduct special research, and the elimination of environmental threats requires the development of comprehensive programs based on systematization and generalizing analysis of the results obtained.

It should be taken into account that negative changes in environmental conditions can be caused not only by the destruction of objects and uncontrolled development of the natural and technical system on the territory of the depressed area. Dangerous phenomena can also occur as a result of external factors. Thus, a catastrophic deterioration of the 
environmental situation in the city can lead the fire spread on the territory of depressed area, emerged outside. Flooding during abnormal precipitation can lead to contamination of a large region with harmful substances stored or accumulated in the depressed area.

To ensure that the various environmental risks inherent in depressed areas are fully taken into account, it is necessary to distinguish their main types. For this purpose, the classification of environmental risks by $K$. A. Oleynik [19], adapted to the specifics of depressed areas, is applicable. The main ones are:

1. Risks of permanent technogenic impacts caused by pollution and other negative changes in the environment of depressed areas in the absence of accidents at its facilities.

2. Risks of permanent biological and sanitary-epidemiological impacts, which consist in the threat of the spread of undesirable organisms and pathogens from the depressed area.

3. Risks of negative impacts in the event of man-made emergencies in the depressed area (fire, depressurization of tanks with toxic substances, etc.).

4. Risks of negative impacts during the development of emergency situations in the depressed area that occurred outside of it.

The development of emergency situations is understood as the emergence of new dangerous factors. So, when a fire spreads to the territory of a depressed area and the materials stored there ignite, highly toxic substances can get into the air. The possibility of such events occurring as a result of a combination of natural processes and human activity is designated as natural and man-made risks.

1. Social and environmental risks caused by environmental degradation as a result of illegal use of depressed areas by the population.

When developing programs for the renovation of depressed areas, it is necessary to identify all the listed risks. Ignoring any of them can cause significant financial and environmental damage, and create a threat to the life and health of the population. For example, laying new underground utilities in an abandoned industrial zone can lead to depressurization of unaccounted-for toxic waste storage facilities.

\section{New unified methodology for developing programs for renovation of depressed areas}

The use of transpersonal socionics under planning any activity implies consistent implementation of actions in accordance with its methodological principles [12], presented in table 2. The renovation program developed on their basis is applicable to all categories of depressed areas. It provides an opportunity for a unified approach to developing a strategy for a given activity and minimizing the risk of its failure.

Table 2. Application of methodological principles of transpersonal socionics under the development of renovation program.

\begin{tabular}{|l|l|l|l|}
\hline $\begin{array}{l}\text { Order } \\
\text { of } \\
\text { actions }\end{array}$ & \multicolumn{1}{|c|}{$\begin{array}{c}\text { Methodological } \\
\text { principle }\end{array}$} & \multicolumn{1}{|c|}{$\begin{array}{c}\text { Implementation of the } \\
\text { principles }\end{array}$} & $\begin{array}{l}\text { Consequences of ignoring } \\
\text { the principles }\end{array}$ \\
\hline 1 & $\begin{array}{l}\text { Priority of the main } \\
\text { stakeholder's } \\
\text { interests }\end{array}$ & $\begin{array}{l}\text { Justification of compliance of } \\
\text { renovation results with the } \\
\text { interests of the stakeholder } \\
\text { sponsoring this activity }\end{array}$ & $\begin{array}{l}\text { Declaration of intentions to } \\
\text { renovate depressed areas in } \\
\text { the absence of funds for } \\
\text { their implementation }\end{array}$ \\
\hline 2 & $\begin{array}{l}\text { The definition of the } \\
\text { ultimate goal }\end{array}$ & $\begin{array}{l}\text { Specification of areas of work } \\
\text { and forecast of expected results }\end{array}$ & $\begin{array}{l}\text { Unjustified costs and new } \\
\text { risks }\end{array}$ \\
\hline 3 & $\begin{array}{l}\text { Setting specific } \\
\text { imadlines for the } \\
\text { implementation of } \\
\text { activities }\end{array}$ & $\begin{array}{l}\text { Limiting the timing of } \\
\text { individual activities to a time } \\
\text { interval that does not cause a a } \\
\text { critical violation of the living }\end{array}$ & $\begin{array}{l}\text { Sharp deterioration in the } \\
\text { quality of life of the } \\
\text { population during the } \\
\text { renovation period }\end{array}$ \\
\hline
\end{tabular}




\begin{tabular}{|l|l|l|l|}
\hline & & conditions of the population & \\
\hline 4 & Conventionality & $\begin{array}{l}\text { Early coordination with } \\
\text { stakeholders the results of the } \\
\text { renovation }\end{array}$ & $\begin{array}{l}\text { Negative attitude of } \\
\text { stakeholders to the results } \\
\text { of renovation }\end{array}$ \\
\hline 5 & $\begin{array}{l}\text { Preventive } \\
\text { elimination } \\
\text { contradictions }\end{array}$ of & $\begin{array}{l}\text { Development of a system for } \\
\text { monitoring possible } \\
\text { contradictions in the } \\
\text { relationships of stakeholders } \\
\text { during the renovation period and } \\
\text { mechanisms for their settlement }\end{array}$ & $\begin{array}{l}\text { Occurrence of conflict } \\
\text { situations in the renovation } \\
\text { process }\end{array}$ \\
\hline
\end{tabular}

Renovation of depressed areas is real only if there is a stakeholder who has the strength and means to carry out this activity. It is considered as the main one, since it not only creates the material base, but also determines the direction of work. It is obvious that the planned activity should correspond, first of all, to its interests. As long as there is no such stakeholder, all attempts to solve the problems of depressed areas inevitably take the form of declarative statements. They can draw attention to the issue of renovation, but not solve it. This situation often lasts for decades. Thus, the construction of a hospital in the Moscow district of Khovrino was stopped in 1985. By this time, huge buildings with a total area of 100 thousand $\mathrm{m}^{2}$ had already been erected, occupying a plot of 2.4 hectares. In 2012, the restoration of this object was officially recognized as impossible. Having existed for more than 30 years, the depressed area has become one of the most dangerous places in the city. In addition to various extreme persons, it was used by criminal elements and banned religious sects. These issues were repeatedly discussed in the media. But the demolition of abandoned buildings began only in 2018 as part of the state program of renovation of the housing stock in Moscow. Then a tender was announced for the development of this area, which attracted organizations for which the implementation of this activity was economically profitable and who were ready to invest in it.

Various aggregate elements of society can act as the main stakeholder. Thus, when resuming construction on an abandoned object, the priority is the economic stakeholder who invests in this activity. Its goal is to complete the capital construction project. But if the owner of the object has gone bankrupt, and there are no investors, the main one may be an administrative stakeholder. His interests may be different. For example, this is the demolition of a building or structure that worsens the social attractiveness of the urban territory and the environmental situation on it.

Compliance with the principle of priority of the interests of the main stakeholder does not mean ignoring the interests of other parties affected by this problem, but they can only be implemented in the course of activities that the main stakeholder determines. In addition, the main stakeholder can be represented by several different organizations (for example, a group of investors) that have joined together to perform a single task. Therefore, in functional terms, such organizations can be considered as a single stakeholder.

The next stage in the development of the renovation program is to determine the final goal. This means specifying the direction and methods of work, as well as predicting the expected results. The results of the analysis of possible consequences should be objective. They should include not only planned positive achievements, but also an assessment of the economic, social and environmental risks of the planned activities. Identification of risks at this stage of development of the depressed area renovation program allows timely inclusion of measures to reduce them.

In world practice, there are several main ways of depressed areas renovation $[8,10$, 20]:

1. Liquidation, which means the demolition of all objects that exist within this area, and the clearing of its territory. If necessary, reclamation measures are carried out, for 
example, removal and disposal of contaminated soil with subsequent filling of the fertile soil layer. After that, new objects are built on the vacant square.

2. Modernization, i.e. updating existing objects while preserving their functions. For depressed housing stock objects, modernization consists of major repairs of buildings and improvement of the surrounding area. Modernization of industrial facilities and industrial zones is usually carried out on the basis of the introduction of new technology while maintaining the nature of production activities.

3. Re-functionalization - reconstruction of buildings and structures of depressed area to turn them into objects used for fundamentally different purposes. For example, the creation of so-called art clusters, i.e. complexes of buildings that preserve their historical appearance and combine the functions of business centers or cultural objects, based on abandoned structures of urban industrial zones. An example is the reconstructed buildings of the former "Krasny Oktyabr" factory in the central part of Moscow.

4. Partial re-functionalization, which includes the reconstruction of certain elements of depressed areas, such as those that pose a danger or hinder the use of the territory (broken water supply and sewerage systems, destroyed pavements of transport communications, etc.). This method of renovation is often used when turning depressed urban areas and ghost towns into tourist sites.

The importance of setting specific deadlines for work completion when developing renovation programs is due to the increased risks of social stakeholders during this period. The elimination of degraded industrial zones deprives the population of jobs and worsens their quality of life. This forces people to engage in new, often dangerous or illegal activities. One of the ways to solve the problem is to limit the renovation period to a time interval that does not cause a critical violation of the living conditions of the population. Another way is to provide the population with jobs during the transition period. Ignoring this problem can have very undesirable consequences. For example, a large state-owned coal mining enterprise in the Nalaikh region (Mongolia) was closed in 1994. The renovation of this industrial zone for a long period was carried out in the form of separate measures with the transfer of rights to coal mining to private companies. Currently, this problem is being solved again at the state level. Thus, the renovation process lasted for several decades. During this time, the work of private firms was carried out without compliance with labor protection rules. For this reason, more than 200 people died in Nalaikh and more than 700 people were seriously injured. Near residential buildings, subsidence and sinkholes have formed on the surface, creating a danger to the population.

The principle of conventionality implies reaching a consensus among all stakeholders on the result of the planned activity. It is this adjusted project, taking into account the interests of all parties, that should be considered as the expected result. The consensus of stakeholders should be understood not as the formalization of official approvals, but as the early development of a mutually acceptable solution to the problem. In particular, sociological research on the needs of social stakeholders can play an important role. Their lack of accounting can negate all renovation efforts. In this regard, China's experience in housing renovation is interesting. This problem is very acute. In large cities, such as Beijing, many residential buildings, including those in disrepair, are heavily overcrowded. According to the press, many people legally live permanently in bomb shelters located under the city. To solve this problem, the authorities have implemented a major project, which to some extent can also be considered as the renovation of depressed areas. In a short time, several dozen cities were built with comfortable living conditions and developed infrastructure, which were supposed to accommodate citizens from overpopulated and dilapidated urban districts [17,21]. The objects were not built on the sections of depressed areas, but allowed people to settle out of them, which opened the possibility for their renovation. However, ignoring the principle of conventionality when developing a program 
for such large-scale construction has led to the fact that by now most of these cities are inhabited by less than $10 \%$. Of these, 50 (including 8 regional centers) were officially recognized as ghost towns in 2014. The main reason for this phenomenon was the lack of consideration of the nature of interests and opportunities of social stakeholders. So, many residents of Chinese cities were afraid to lose their jobs when moving to a new place of residence. Other residents of depressed areas were unable to buy new housing due to the high cost. In addition, the operation of technological and economic stakeholders that ensure the operation of public utilities, public transport, shops, and consumer services in new uninhabited cities has proved unprofitable. As a result, a vicious circle of interrelated problems has emerged: the population cannot exist normally in the absence of urban infrastructure, which can only start working when the population appears in cities. To solve these problems, the Chinese authorities are forced to take various additional measures and spend significant funds after the renovation project is completed. Governments move to ghost towns from neighboring cities, place educational institutions in it, and provide certain benefits to those who want to move. But that hasn't solved the problem of Chinese ghost towns yet.

Compliance with the principle of preventive elimination of contradictions is to predict and promptly control the occurrence of conflict situations in the relationships of stakeholders during the renovation process. Contradictions between interested parties often arise already in the course of work when unforeseen circumstances arise. Most often, they are caused by an unfavorable change in the economic situation, which forces the main stakeholder to stop renovation activities. This is usually accompanied by a deterioration in the situation of social stakeholders, for whom the duration of the transition period with a concomitant deterioration in the quality of life increases indefinitely. To prevent possible conflicts, the program of renovation of depressed areas should include a system for monitoring the causes that can cause contradictions, and agree in advance with all interested parties the mechanisms for their resolution.

\section{Conclusions}

1. The existence of depressed areas inevitably causes deterioration of the social, economic and environmental situation. In many cases, such urban sections tend to expand their borders spontaneously. For these reasons, the renovation of depressed areas is a necessary condition for ensuring the safety and normal living conditions of the population.

2. Using the principles of transpersonal socionics allows providing a systematic unified approach to the development of programs for the renovation of depressed areas, based on taking into account all parties involved in this problem (stakeholders).

3. When developing renovation programs, special attention should be paid to solving related environmental problems, that pose a threat to the life of the population, and assessing the risks associated with environmental problems.

\section{References}

1. A.L. Suzdaleva, Safety in Technosphere 5(3), 6-14 (2016)

2. V.I. Torgovchenkov, Safety as an integral part of urban planning. Zakonnost' 10, 7-9 (2013)

3. A.K. Shardakov, I.N. Rosuschan, Dyl'novskie chteniya "Sociologicheskaya diagnostika sovremennogo obshchestva", 362-364 (2016)

4. I.A. Zubarev, A.V. Shutka, Nacional'naya associaciya uchenyh 55, 4-7 (2020) 
5. P.E. Graves, S. Weiler, E.E. Tynon, Journal of Regional Analysis and Policy 39(2), 131-140 (2009)

6. I.A. Yashkov, A.V. Ivanov, A.S. Kuskov, V.A. Baranov, "Dead" cities in the geoecological and cultural space (Izdatel'skij dom «Kamerton», Moscow, 2010)

7. C. Alpopia, C. Manole, Procedia Economics and Finance 6, 178-185 (2013)

8. R.A. Drozhzhin, Vestnik Sibirskogo gosudarstvennogo industrial'nogo universiteta 1(11), 84-86 (2015)

9. S. Cevik, S. Vural, F. Tavsan, O. Asik, Building and Environment 43, 950-962 (2008)

10. S.V. Ilkevich, P. Strömberg, Service plus 11(4), 4-13 (2017)

11. A.L. Suzdaleva, Ecology of Urban Areas 3, 12-17 (2015)

12. O. Gamayunova, M. Petrichenko, A. Mottaeva, Journal of Physics: Conference Series 1614, 012066 (2020) doi:10.1088/1742-6596/1614/1/012066

13. A.L. Suzdaleva, V.N. Beznosov, A.A. Suzdaleva, Nacional'nyj imidzh 01(06), 50-55 (2009)

14. A.L. Suzdaleva, V.N. Beznosov, Ecology and development of society 1(3), 23-27 (2012)

15. A.L. Suzdaleva, V.N. Beznosov, A.A. Suzdaleva, Ecology of Urban Areas 3, 29-34 (2012)

16. L. Mingye, China perspectives 1, 69-78 (2017)

17. I. Yashkov, A. Ivanov, T. Vinogradova, Urban Studies 4, 27-42 (2016)

18. K.A. Oleinik, Environmental risks of financial and economic activities: methodological issues and world experience. Author's abstract. dis. for a job. learned. step. Ph.D. (MGIMO, Moscow, 2002)

19. M.I. Akimova, V.S. Milinchuk, Trudy Novosibirskogo gosudarstvennogo arhitekturnostroitel'nogo universiteta (Sibstrin) 2, 49-59 (2018)

20. O.K. Piller, D.V. Buyarov, Sbornik Vostochnogo centra 18, 27-31 (2016) 